LOCAL WISDOM, 13 (1): 1- 12, 2021
Local Wisdom Scientific Online Journal
ISSN: 2086-3764

\title{
Spatial Adaptation of Traditional Javanese Houses in Landscape Design of Senaputra Cultural Tourism Park
}

\author{
Stivani Ayuning Suwarlan ${ }^{*}$ \\ ${ }^{1}$ Architecture Study Program of Faculty of Civil Engineering and Planning Batam International \\ University, Indonesia \\ Corresponding Author: : stivani@uib.ac.id
}

\begin{tabular}{|c|c|}
\hline & Abstract \\
\hline $\begin{array}{l}\text { Keywords: } \\
\text { cultural park, } \\
\text { Javanese culture, } \\
\text { Javanese } \\
\text { traditional house, } \\
\text { revitalization }\end{array}$ & $\begin{array}{l}\text { One of the efforts to preserve Indonesian culture and heritage is through } \\
\text { cultural tourism parks. Therefore, the existence of a cultural tourism } \\
\text { park is very important because it has Indonesian cultural values. The } \\
\text { problem currently faced by Indonesia, especially Malang City, East Java, } \\
\text { is the number of new modern tourism parks that make cultural tourism } \\
\text { parks less attractive. The rise number of modern tourism parks in } \\
\text { Malang has reached } 100 \% \text { in the last } 5 \text { years, while there has been no } \\
\text { addition of cultural parks in Malang. As what happened at the } \\
\text { Senaputra Cultural Tourism Park, Malang that is famous as a park that } \\
\text { preserves traditional culture, especially East Java culture. In the glorious } \\
\text { era of Taman Senaputra in 1980s, traditional East Javanese dances and } \\
\text { wayangkulit performances were often held. The research method used } \\
\text { quantitative and qualitative research. First, through observation to } \\
\text { determine the factual conditions of the research area using walkthrough } \\
\text { analysis techniques. Second, through questionnaires to find out } \\
\text { communities perceptions of preferences between modern parks } \\
\text { compared to cultural parks and to find out the communities perception } \\
\text { of the Senaputra cultural park main problems. The results of the } \\
\text { questionnaire were processed using SPSS and analyzed using a linkert } \\
\text { scale to determine the priority scale of main problems. The results of this } \\
\text { study showing people preferences and perception index score of modern } \\
\text { park } 82.04 \% \text { and cultural park } 17.96 \% \text {. The main problem of less } \\
\text { preferences index score of cultural park is due to of the irregular } \\
\text { landscape arrangement of the cultural park and does not have the } \\
\text { characteristics of Javanese culture as a cultural park and author } \\
\text { observation's resulted that this park also lacks of maintenance and most } \\
\text { of park elements are damaged, so there is a need for design directions } \\
\text { from the landscape side which has the character of Javanese culture in an } \\
\text { effort to revive (revitalize) the cultural tourism park so that it is again in } \\
\text { demand and cultural values as the national identity are not forgotten } \\
\text { and lost. }\end{array}$ \\
\hline
\end{tabular}

DOI: https://doi.org/10.26905/lw.v13i1.4770

Article History Received : Sept 7, 2020

@ 2017 The Authors. Published by GKAK UNMER Malang

Accepted : Oct 23, 2020

Published : January 15, 2021 


\section{Spatial Adaptation of Traditional Javanese Houses in Landscepe Design of Senaputra Cultural Tourism Park \\ Stivani Ayuning Suwarlan}

\section{INTRODUCTION}

Indonesia is a country known for its plethora culture, where culture is a form to express the harmony and balance of physical geographic and environment which has been around since time immemorial (Junianto, 2019). Indonesian culture is one of the characteristics of a nation that carry the history and legacy of the Indonesian nation. For that, Indonesian culture must be sustainable and its existence maintained. One of the efforts to maintain and preserve culture is through cultural tourism which has cultural values as the main attraction (Prasodjo, 2017). Cultural tourism requires a place that can attract people and accommodate Indonesian culture and provide knowledge about culture. One of these places is a cultural tourism park that provides entertainment as well as knowledge of traditional cultural arts. Cultural tourism parks are very important because the nation's culture must be maintained and not forgotten over time. Given the number of modern tourism parks nowadays, tourism parks that are thick with culture are starting to be abandoned so that to attract the interest of visiting tourists, a strategy is needed in introducing and maintaining cultural heritage (Kirom, 2016).

Malang is one of regional in Java Island and part of East Java Province that have Javanese culture and heritage. In 1980s, Malang provide cultural tourism park named "Senaputra" to preserve the Javanese culture and entertain for the communities. Senaputra is one of the cultural tourism parks in the Malang city which was once well known as a park of Javanese traditional culture and arts, especially East Java art through the performance of traditional dances and wayangkulit, the traditional shadow puppet performace. In addition, there are traditional dance studios for the communities, especially for children and adolescents who want to learn and preserve cultural arts. At that time Senaputra cultural park became the number one tourism park in Malang city.

In 2000s, Senaputra start facing the problem due to the rise of several new parks caused Senaputra less attractive to the public. In fact, apart from the age factor of Senaputra cultural park, Senaputra cultural park was inferior to other tourism parks that are more modern and attractive. Since 2019, Malang has 110 tourism attractions where there are only 10 tourism attractions that have cultural and historical values and the rise number of modern tourism parks in Malang has reached 100\% in the last 5 years, while there has been no addition of cultural parks in Malang (East Java Tourism and Culture Office 2020). That data indicated, a very rapid increase in the number of modern tourism compared to cultural and historical tourism.

The goal to be achieved in this study is to revitalize or revive the Senaputra cultural park, which was once popular in the 1980s, to be alive and popular again in the present year. Revitalization is an effort to improve the quality of a function or certain areas that have been functionally degraded, environment, and visually through various specific and containing ways understanding of efforts to use, protect, maintain and increasing social and cultural values (Sri Hidayati, 2000). Moreover, revitalization is an effort to treat and revive a certain local wisdom, culture, heritage or tradition (Mattulada, 2000). It is hoped that this park could be attracted by the communities. For this reason, efforts are needed to revive (revitalize) the Senaputra Cultural Tourism Park so that it is again in demand so that the existence and values of Indonesian culture as a national identity especially Javanese traditional culture are not forgotten by future generations and lost with age.

The research method used mixed quantitative and qualitative research. First, through observation to determine the factual conditions of the research area using walkthrough analysis techniques. Second, through questionnaires to find out communities perceptions of preferences between modern parks compared to cultural parks and to find out the communities perception of the Senaputra cultural park main problems. The results of the 


\section{Spatial Adaptation of Traditional Javanese Houses in Landscepe Design of Senaputra Cultural Tourism Park \\ Stivani Ayuning Suwarlan}

questionnaires were processed using SPSS and analyzed using a linkert scale to determine the priority scale of main problems. The main problems of Senaputra cultural park would become the basis of revitalize design.

\section{METHODOLOGY}

This study use mixed quantitative and qualitative research. Descriptive methods is chosen for this research to describe and analyze existing and real situations in the research area. Descriptive method is chosen because the research conducted is relating to the actual conditions. The research data collection is through observation and questionnaires. Observation is a data collection technique that has specific characteristics with regard to human behavior, work processes, natural phenomena, and the observed respondents. These observations provide convenience, especially in terms of obtaining data in the research area. Questionnaire is a data collection technique that is done by giving a set of questions or written statements to respondents to answer (Sugiyono, 2018).

For observation data collection, it is combine with walkthrough analysis. Walkthrough analysis is one of an urban design technique for collecting data, observation and analyze the real situation in the field of research area. Walkthrough analysis is observation of a place recorded by photograph or sketchs done by walking through the research area. This technique can identify and analyze the problem and real condition of the area closely (Ministry For The Environment, 2009). For questionnaires data collection were processed and analyzed using SPSS and linkert scale, score for positive answers are given a score of 5-4-3-2-1, while for answers negatives are given a score of 1-2-3-4-5. The scoring results are then stated in a complete recapitulation table (tabulating). According to (Siregar, 2016) the likert scale is a scale that can be used to measure attitudes, opinions and perceptions of a person about a particular object or phenomenon. This phenomenon has been specifically determined by the author, hereinafter referred to as research variable.

This study used 25 questions given to 100 respondents. The questions used were first tested for validity and reliability. Validity test is to shows the extent of a measuring instrument is able to measure. A measurement instrument is said to be valid if the instrument can measure something exactly what it wants to measure. If $r_{\text {count }}$ with $r_{\text {tabel }}$ with significance level of 0.05 . If $r_{\text {count }}<r_{\text {tabel, }}$, then the instrument is declared invalid and if $r_{\text {count }}>$

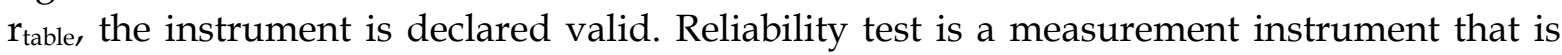
reliable if the measurements are consistent and meticulously accurate so that the results of a measurement can be trusted. Reliability test in this study using Cronbach Aplha method by SPPS software. If Cronbach Alpha value of $<0.6$ indicates that no reliable research instrument, then Cronbach Alpha value> 0.6 indicate that reliable research instrument (Siregar, 2016).

\section{MATERIAL}

Resulting the validity test of the instrument of 25 questions shown in Table 1 bellow. The result note of 25 item questionnaire statement on the variable $(Y)$ has $r_{\text {tabel }}$ value 0.195 and $r_{\text {count }}$ value between 0.684 until 0.911 . The validity test has a value $r_{\text {count }}>r_{\text {tabel }}$ indicates that the 25 item of the statement can be said to "Valid". Therefore, all items instrument in this study can be used and given to the respondents. 
Validity Test

\begin{tabular}{|c|c|c|c|c|c|c|c|c|c|}
\hline No. & variable mame & R Count & R Table & Information & Na. & rariable mame & R Count & R Table & Information \\
\hline 1 & $\mathrm{Y} 1$ & 0.752 & 0.195 & valid & 15 & Y15 & 903 & 0.195 & valid \\
\hline 2 & $\mathrm{Y} 2$ & 0.803 & 0.195 & valid & 16 & Y16 & 0.823 & 0.195 & valid \\
\hline 3 & $\mathrm{Y} 3$ & 851 & 0.195 & valid & 17 & Y17 & 863 & 0.195 & valid \\
\hline 4 & Y4 & 846 & 0.195 & valid & 18 & Y18 & .787 & 0.195 & valid \\
\hline 5 & Y5 & .684 & 0.195 & valid & 19 & Y19 & 851 & 0.195 & valid \\
\hline 6 & Y6 & 0,813 & 0.195 & valid & 20 & $Y 20$ & 0,782 & 0.195 & valid \\
\hline 7 & $\mathrm{Y}^{7}$ & 0.827 & 0.195 & valid & 21 & Y21 & 0.831 & 0.195 & valid \\
\hline 8 & Y8 & 0.812 & 0.195 & valid & 22 & Y22 & $\$ 10$ & 0.195 & valid \\
\hline 9 & Y9 & 0.858 & 0.195 & valid & 23 & Y 23 & 0.899 & 0.195 & valid \\
\hline 10 & Y10 & 0.822 & 0.195 & valid & 24 & Y24 & 0911 & 0.195 & valid \\
\hline 11 & Y11 & 0.782 & 0.195 & valid & 25 & Y 25 & 0.831 & 0.195 & valid \\
\hline 12 & $\mathrm{Y} 12$ & 890 & 0.195 & valid & & & & & \\
\hline 13 & Y13 & .798 & 0.195 & valid & & & & & \\
\hline 14 & Y14 & 873 & 0.195 & valid & & & & & \\
\hline
\end{tabular}

Table 1. The Result of Validity Test

\section{Reability Test}

\begin{tabular}{|cc|}
\hline \multicolumn{2}{|c|}{ Reliability Statistics } \\
\hline Cronbach's Alpha & N of Items \\
\hline $\mathbf{0 9 6 4}$ & 25 \\
\hline
\end{tabular}

Table 2. The Result of Reability Test

Tabel 2 above shown the results of reliability test is 0.964 . This result of testing people's perceptions and preferences can be concluded that the data obtained is reliable because it has a Cronbach's Alpha value> 0.6. It is seen that the questionnaire (research instrument) is reliable, consistent or trustworthy. As the result of validity and reability test above, seems that the measurement instruments in questionnaires data collection are trusted, clear and valid for using in measuring in this study.

\section{Spatial Character in Javanese Traditional Culture}

Space is a relationship between objects and humans who feel the existence of that space. The boundaries of a space can be influenced by the human senses of sight, smell, hearing and touch (Lake, 2020). The character of a Javanese traditional house is the symbolic organization of the spaces in the house (spatial coordinates), that is inherent in the layout concept of Javanese traditional house. Javanese traditional culture recognizes two spatial characters, namely spatial organization and spatial hierarchy in the layout design of a Javanese traditional house. The two spatial characters are an absolute concept or symbol and must exist in a Javanese traditional house layout desain.

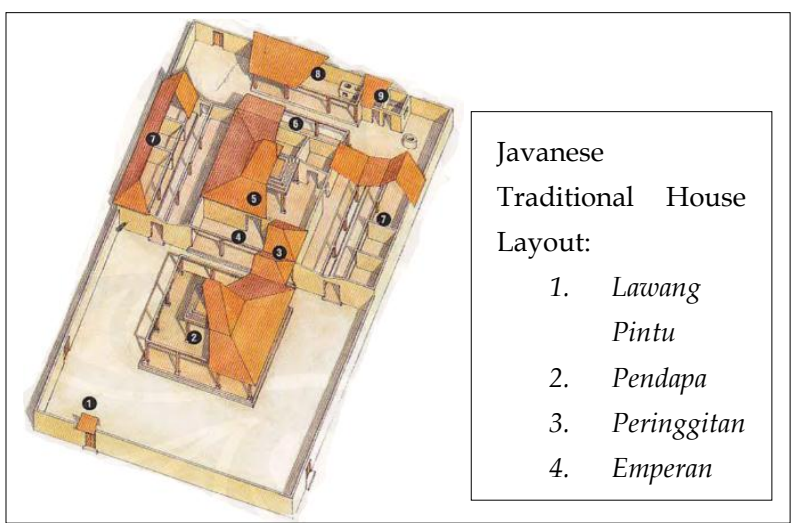

Figure 1. Javanese Traditional House Layout. source: (Wahyudi, 2006) 


\section{Spatial Adaptation of Traditional Javanese Houses in Landscepe Design of Senaputra Cultural Tourism Park \\ Stivani Ayuning Suwarlan}

\section{a. Spatial Organization of Javanese Traditional House}

A traditional Javanese house has a very complex layout with various levels of spatial characteristics from public to private and levels of spatial primacy. According to (Frick, 1997)the parts of space in a traditional Javanese house are: 1) Pendhopo (terrace), located at the front with its main function to gather and receive guests. This section is always open without wall dividers or dividers. The pavilion also functions like a stage (podium) because the audience can see the activity from all three sides, namely the front, right side and left side; 2) Pringgitan, a place between the pavilion and the palace which functions as a wayang kulit show; 3) Dalem Ageng, the most important part of a traditional Javanese house. It is the center of space that functions as a family room that is private, quiet and authoritative; 4) Sentong, in the form of three lined rooms. In senthong kiwo (left) and senthong tengen (right) it is used for the bedroom of the owner. Senthong tengah is a special room as a place of worship and storage of heirlooms; 5) Gandok, houses next to dalem agung. Gando kkiwo (left) is used for sleeping for women, while gandoktengen (right) is for sleeping for men. The atmosphere is relaxed and informal; 6) Gadri, the dining room which is located behind senthong and dalem agung. Gadri is semi open, the atmosphere is relaxed and friendly; 7) Kitchen/pawon and pekiwan, service area and located at the back. This section includes the kitchen, bathroom and well.

A Javanese traditional house with complete spatial organization is quite complex with lots of space, so it consists of several buildings. The building of Javanese traditional house divided into infront building, main or center building, side (left and right) building and back building. The pendopo building is located at the front, followed by the pringgitan and dalem. Then on the left and right are the gandok and on the back there are gadri and pawon/kitchen as seen in Figure 2 below.

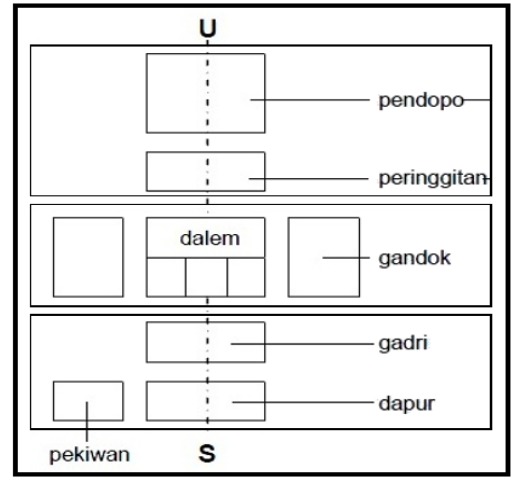

Figure 2. The Spatial Organization of Javanese Traditional House. source: (Wahyudi, 2006)

\section{b. Spatial Hierarchy of Javanese Traditional House}

The hierarchy of space is an essential part of the spatial layout pattern. The space hierarchy is the difference in the character of the space which has the highest to lowest intensity of activities carried out by residents (Sari, 2020). Javanese traditional culture recognizes various levels of order. This is also reflected in Javanese traditional houses that recognize spatial hierarchy. In Figure 3, explaining the front yard (terrace), pendhopo and peringgitan as a place to receive guests is a public zone, while the dalem and gandok areas are semi-private spaces for occupant activies. Senthong as main bedroom and holy room is the most private area in Javanese house layout and gadri, pekiwan, pawon as the service area. 




Figure 3. The Spatial Hierarchy of Javanese Traditional House. source: (Author, 2020)

\section{Location Map}

Senaputra Cultural Tourism Park is located in the center of Malang, precisely in the Klojen area. The following is a map of the location of Taman Senaputra captured from satellite imagery and then transformed into a graphic image.Senaputra cultural park map along with pathways direction use in walkthrough analysis technique seen in Figure 4 below.
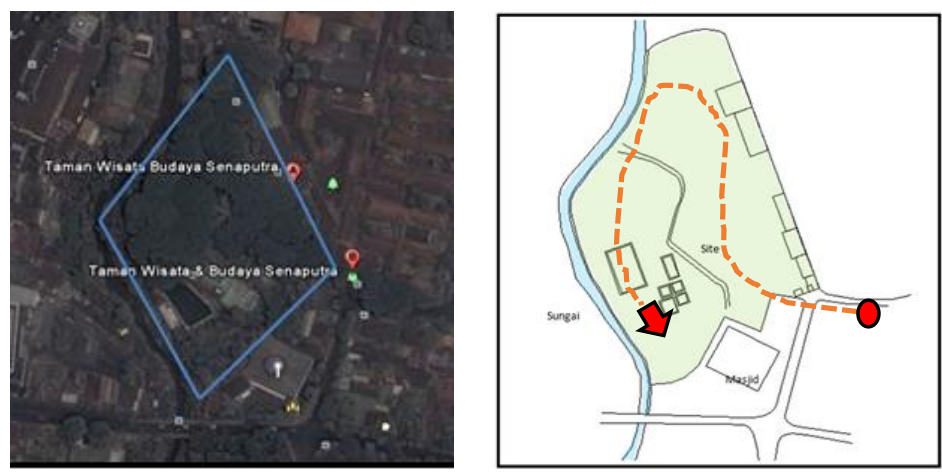

Figure 4. Senaputra Cultural Park Map. source: (google earth 2019)

\section{RESULTS AND DISCUSSION}

\section{Observation (Walkthrough Analysis) Result}

To find out the assessment or the perspective of the researcher/author towards the condition and characteristics of research area, the walkthrough analysis technique was used. This analysis technique is related to the city image theory from Lynch, 1960 which focuses on the path. Observation's resulted that this park also lacks of maintenance and most of park elements are damaged seen as Table 3 bellow. Senaputra as a cultural park have less Javanese cultural value and landscape obscurity layout.

\begin{tabular}{|c|c|c|}
\hline No & Views & Result views \\
\hline 1 & $\begin{array}{l}\text { Sishooting point } \\
\text { : shooting direction }\end{array}$ & $\begin{array}{l}\text { The entrance to the Senaputra Cultural Park is poorly maintained } \\
\text { and has banners attached haphazardly spoil the aesthetics and } \\
\text { discourage visitors. }\end{array}$ \\
\hline
\end{tabular}


Stivani Ayuning Suwarlan

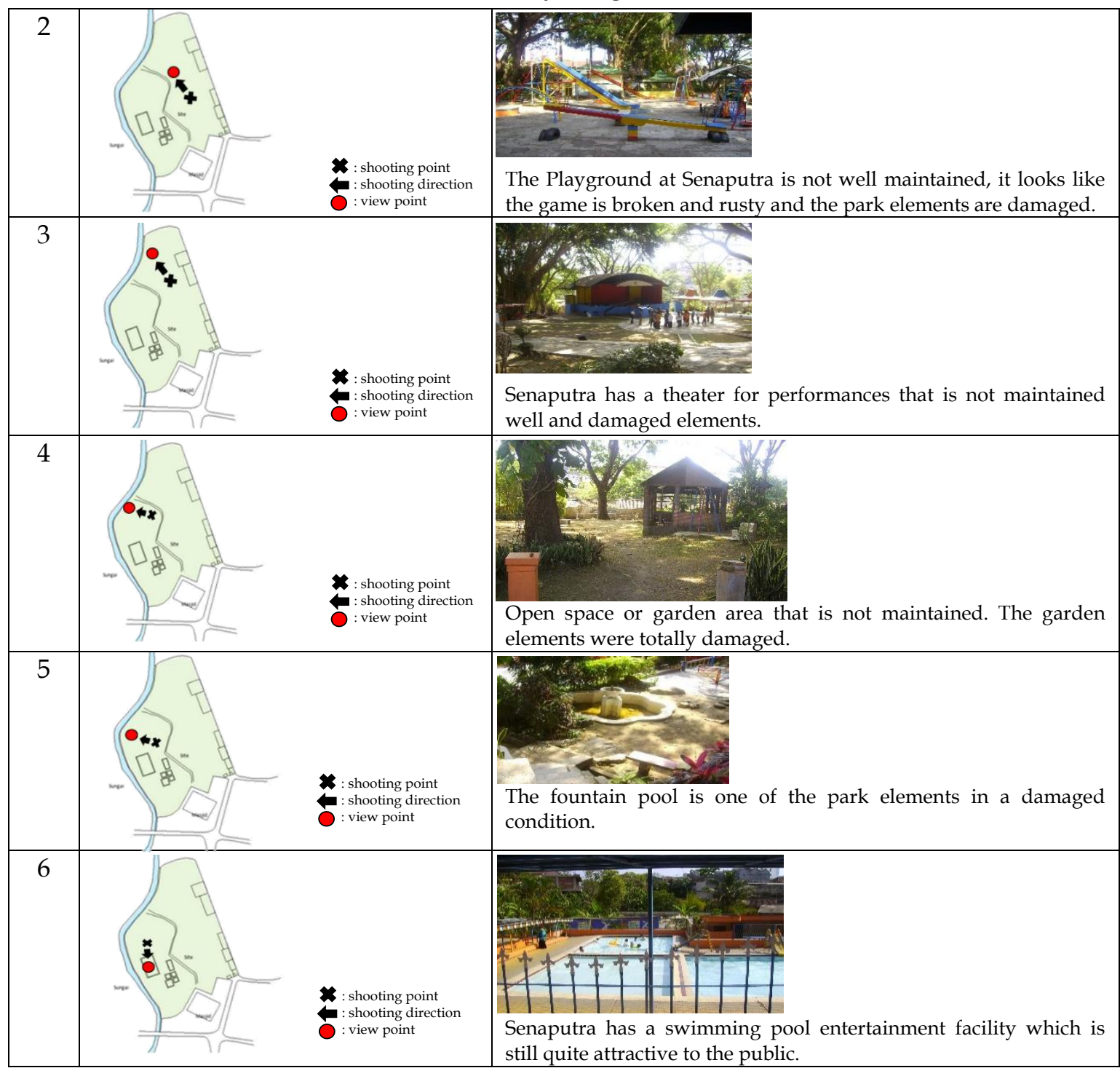

Table 3. Walkthrough Analysis, Single Directional Views (Observation Result)

\section{Analysis Community Preferences and Perceptions Result}

The results of this study showing people preferences and perception index score of modern park is $82.04 \%$ and cultural park is $17.96 \%$ as seen on Table 4 . For the conclusion of the data analysis is the main problem of less preferences dan perceptions index score of cultural park is due to of the irregular landscape desain of the cultural park and does not have the characteristics of Javanese culture as a cultural park and author observation's resulted that this park also lacks of maintenance and most of park elements are damaged, so there is a need for design directions from the landscape side which has the character of Javanese culture as Senaputra cultural park characters. The landscape schematic design and space program was adapting from spatial characters of Javanese culture which is implemented in Javanese traditional house. 


\begin{tabular}{|c|c|c|c|c|c|c|}
\hline \multirow{2}{*}{ Respondent } & \multicolumn{7}{|c|}{ Score Item } & \multirow{2}{*}{ Total } \\
\cline { 2 - 6 } & 1 & 2 & 3 & 4 & 5 & \\
\hline 1 & 0 & 8 & 24 & 28 & 30 & 18 \\
\hline 2 & 1 & 6 & 27 & 32 & 20 & 17.2 \\
\hline 3 & 0 & 2 & 30 & 20 & 35 & 17.4 \\
\hline 4 & 2 & 10 & 24 & 24 & 45 & 21 \\
\hline 5 & 3 & 8 & 27 & 44 & 15 & 19.4 \\
\hline 6 & 1 & 12 & 15 & 32 & 25 & 17 \\
\hline 7 & 4 & 20 & 15 & 16 & 5 & 12 \\
\hline 8 & 3 & 6 & 21 & 36 & 35 & 20.2 \\
\hline 9 & 0 & 6 & 27 & 32 & 20 & 17 \\
\hline 10 & 0 & 2 & 30 & 20 & 35 & 17.4 \\
\hline 11 & 1 & 8 & 24 & 28 & 30 & 18.2 \\
\hline 12 & 2 & 6 & 27 & 32 & 20 & 17.4 \\
\hline 13 & 1 & 10 & 24 & 24 & 45 & 20.8 \\
\hline 14 & 1 & 8 & 24 & 28 & 30 & 18.2 \\
\hline 15 & 4 & 6 & 27 & 32 & 20 & 17.8 \\
\hline 16 & 0 & 8 & 27 & 44 & 15 & 18.8 \\
\hline 17 & 0 & 12 & 15 & 32 & 25 & 16.8 \\
\hline 18 & 2 & 6 & 27 & 32 & 20 & 17.4 \\
\hline 19 & 1 & 8 & 27 & 44 & 15 & 19 \\
\hline 20 & 2 & 8 & 24 & 28 & 30 & 18.4 \\
\hline 21 & 0 & 6 & 27 & 32 & 20 & 17 \\
\hline 22 & 0 & 8 & 24 & 28 & 30 & 18 \\
\hline 23 & 3 & 10 & 24 & 24 & 45 & 21.2 \\
\hline 24 & 3 & 8 & 24 & 28 & 30 & 18.6 \\
\hline 25 & 0 & 6 & 27 & 32 & 20 & 17 \\
\hline 26 & 0 & 8 & 24 & 28 & 30 & 18 \\
\hline 27 & 1 & 10 & 24 & 24 & 45 & 20.8 \\
\hline 28 & 1 & 8 & 24 & 28 & 30 & 18.2 \\
\hline 29 & 0 & 8 & 27 & 44 & 15 & 18.8 \\
\hline 30 & 2 & 6 & 27 & 32 & 20 & 17.4 \\
\hline 31 & 4 & 12 & 15 & 32 & 25 & 17.6 \\
\hline 32 & 1 & 8 & 24 & 28 & 30 & 18.2 \\
\hline 33 & 0 & 2 & 30 & 20 & 35 & 17.4 \\
\hline 34 & 2 & 8 & 24 & 28 & 30 & 18.4 \\
\hline 35 & 0 & 6 & 27 & 32 & 20 & 17 \\
\hline 36 & 0 & 8 & 24 & 28 & 30 & 18 \\
\hline 37 & 3 & 8 & 24 & 28 & 30 & 18.6 \\
\hline 38 & 0 & 8 & 24 & 28 & 30 & 18 \\
\hline 39 & 0 & 2 & 30 & 20 & 35 & 17.4 \\
\hline 40 & 0 & 12 & 15 & 32 & 25 & 16.8 \\
\hline 41 & 3 & 8 & 27 & 44 & 15 & 19.4 \\
\hline 42 & 3 & 8 & 24 & 28 & 30 & 18.6 \\
\hline 43 & 0 & 6 & 27 & 32 & 20 & 17 \\
\hline 44 & 2 & 8 & 24 & 28 & 30 & 18.4 \\
\hline 45 & 0 & 12 & 15 & 32 & 25 & 16.8 \\
\hline 46 & 4 & 8 & 24 & 28 & 30 & 18.8 \\
\hline 47 & 4 & 2 & 30 & 20 & 35 & 18.2 \\
\hline 48 & 0 & 8 & 24 & 28 & 30 & 18 \\
\hline 49 & 2 & 12 & 15 & 32 & 25 & 17.2 \\
\hline 50 & 5 & 6 & 27 & 32 & 20 & 18 \\
\hline & & & & & & \\
\hline
\end{tabular}

\begin{tabular}{|c|c|c|c|c|c|c|}
\hline \multirow{2}{*}{ Respondent } & \multicolumn{5}{|c|}{ Score Item } & \multirow{2}{*}{ Total } \\
\hline & 1 & 2 & 3 & 4 & 5 & \\
\hline 51 & 1 & 8 & 24 & 28 & 30 & 18.2 \\
\hline 52 & 2 & 8 & 24 & 28 & 30 & 18.4 \\
\hline 53 & 0 & 2 & 30 & 20 & 35 & 17.4 \\
\hline 54 & 0 & 8 & 24 & 28 & 30 & 18 \\
\hline 55 & 3 & 6 & 27 & 32 & 20 & 17.6 \\
\hline 56 & 1 & 8 & 24 & 28 & 30 & 18.2 \\
\hline 57 & 0 & 2 & 30 & 20 & 35 & 17.4 \\
\hline 58 & 0 & 8 & 27 & 44 & 15 & 18.8 \\
\hline 59 & 0 & 8 & 24 & 28 & 30 & 18 \\
\hline 60 & 0 & 6 & 27 & 32 & 20 & 17 \\
\hline 61 & 0 & 8 & 24 & 28 & 30 & 18 \\
\hline 62 & 4 & 2 & 30 & 20 & 35 & 18.2 \\
\hline 63 & 0 & 8 & 24 & 28 & 30 & 18 \\
\hline 64 & 0 & 8 & 24 & 28 & 30 & 18 \\
\hline 65 & 0 & 6 & 27 & 32 & 20 & 17 \\
\hline 66 & 5 & 8 & 24 & 28 & 30 & 19 \\
\hline 67 & 5 & 8 & 24 & 28 & 30 & 19 \\
\hline 68 & 0 & 2 & 30 & 20 & 35 & 17.4 \\
\hline 69 & 0 & 8 & 24 & 28 & 30 & 18 \\
\hline 70 & 0 & 8 & 24 & 28 & 30 & 18 \\
\hline 71 & 4 & 6 & 27 & 32 & 20 & 17.8 \\
\hline 72 & 1 & 8 & 24 & 28 & 30 & 18.2 \\
\hline 73 & 0 & 2 & 30 & 20 & 35 & 17.4 \\
\hline 74 & 0 & 8 & 24 & 28 & 30 & 18 \\
\hline 75 & 0 & 6 & 27 & 32 & 20 & 17 \\
\hline 76 & 2 & 8 & 24 & 28 & 30 & 18.4 \\
\hline 77 & 2 & 8 & 24 & 28 & 30 & 18.4 \\
\hline 78 & 0 & 2 & 30 & 20 & 35 & 17.4 \\
\hline 79 & 0 & 8 & 24 & 28 & 30 & 18 \\
\hline 80 & 4 & 6 & 27 & 32 & 20 & 17.8 \\
\hline 81 & 3 & 8 & 24 & 28 & 30 & 18.6 \\
\hline 82 & 0 & 8 & 24 & 28 & 30 & 18 \\
\hline 83 & 0 & 2 & 30 & 20 & 35 & 17.4 \\
\hline 84 & 0 & 8 & 24 & 28 & 30 & 18 \\
\hline 85 & 3 & 8 & 24 & 28 & 30 & 18.6 \\
\hline 86 & 3 & 8 & 24 & 28 & 30 & 18.6 \\
\hline 87 & 0 & 6 & 27 & 32 & 20 & 17 \\
\hline 88 & 0 & 8 & 24 & 28 & 30 & 18 \\
\hline 89 & 0 & 2 & 30 & 20 & 35 & 17.4 \\
\hline 90 & 0 & 8 & 24 & 28 & 30 & 18 \\
\hline 91 & 0 & 8 & 24 & 28 & 30 & 18 \\
\hline 92 & 1 & 8 & 24 & 28 & 30 & 18.2 \\
\hline 93 & 1 & 6 & 27 & 32 & 20 & 17.2 \\
\hline 94 & 0 & 8 & 24 & 28 & 30 & 18 \\
\hline 95 & 0 & 2 & 30 & 20 & 35 & 17.4 \\
\hline 96 & 0 & 18 & 24 & 16 & 15 & 14.6 \\
\hline 97 & 0 & 8 & 24 & 28 & 30 & 18 \\
\hline 98 & 2 & 6 & 27 & 32 & 20 & 17.4 \\
\hline 99 & 1 & 8 & 24 & 28 & 30 & 18.2 \\
\hline 100 & 0 & 8 & 27 & 44 & 15 & \begin{tabular}{|l|l}
18.8 \\
\end{tabular} \\
\hline \multicolumn{6}{|c|}{ Community Preferences and Perceptions of Cultural Park } & 17.96 \\
\hline \multicolumn{6}{|c|}{ Community Preferences and Perceptions of Modern Park } & 82.04 \\
\hline
\end{tabular}

Table 4. Recapitulation Data Linkert Scale (Tabulating)

\section{Adaptation of Javanese House Spatial Organization and Spatial Hierarchy}

1. Adaptation and implementation of the Javanese house spatial organization at the Senaputra Cultural Tourism Park seen in Figure 5 below. The adaptation analysis the characters of each spatial symbol/organizatition as a basis of layout program in Senaputra landscape design. It shown that, each spatial symbol/organizatition could be classified as public, semi public, semi private, prive and service space.

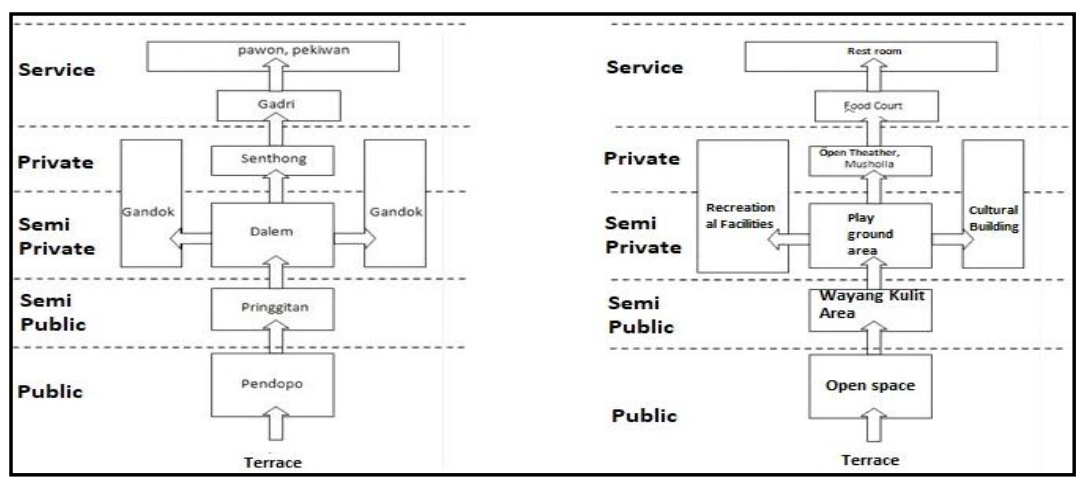

Figure 5. Adaptation Process of Spatial Organization of Javanese Traditional House. source: (Author, 


\section{Spatial Adaptation of Traditional Javanese Houses in Landscepe Design of Senaputra Cultural Tourism Park \\ Stivani Ayuning Suwarlan}

2. Adaptation and application of the hierarchy of Javanese house space in the Senaputra Cultural Tourism Park seen in Figure 6 below. For spatial hierarchy start from spatial organization analysis, implemented in landscape layout space program, which is shown that the public space is located at the front and is followed further in by other spaces as each characters. The spatial hierarchy in Taman Senaputra has a character that is tailored to the activities of the crowded visitors to the lowest or more privacy visitors.

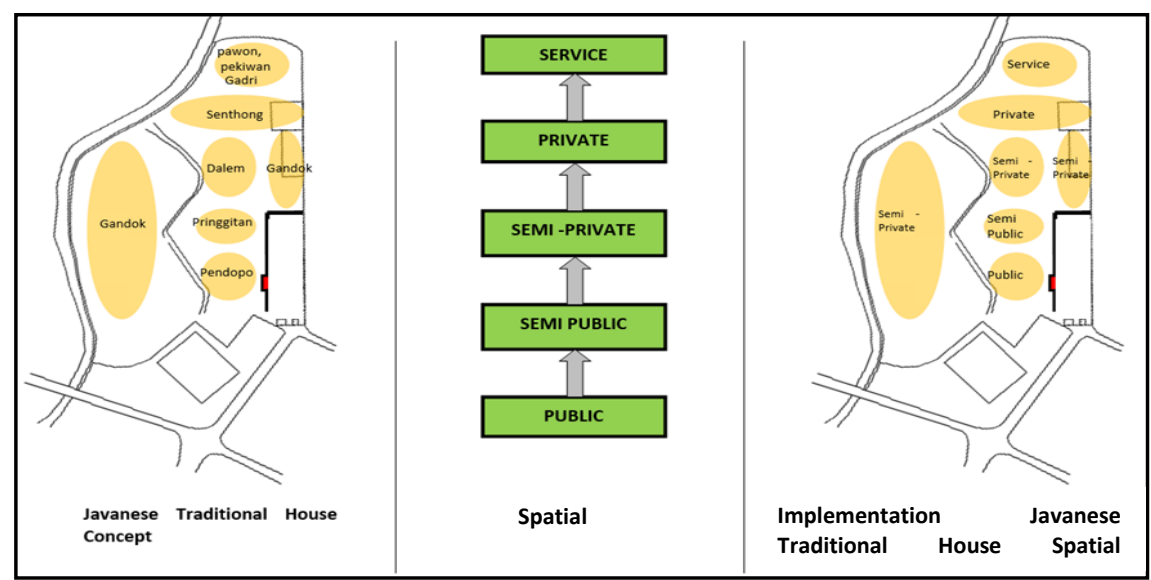

Figure 6. Adaptation Process of Spatial Hierarchy of Javanese Traditional House. source:

(Author, 2020)

\section{Design directions}

The design direction starts from the landscape arrangement (directives) at the Senaputra Cultural Tourism Park by determining the zoning of each park spot as in Figure 7 below. After obtaining zoning of the layout of the park spots based on the character of each spot adapted from the Javanese house, then zoning is produced based on the existing spots of the Senaputra Cultural Tourism Park which can be seen in Figure 8 below. With this implementation, Senaputra park landscape design is produced has a clear spatial organization and spatial hierarchy as Traditional Javanese culture values.

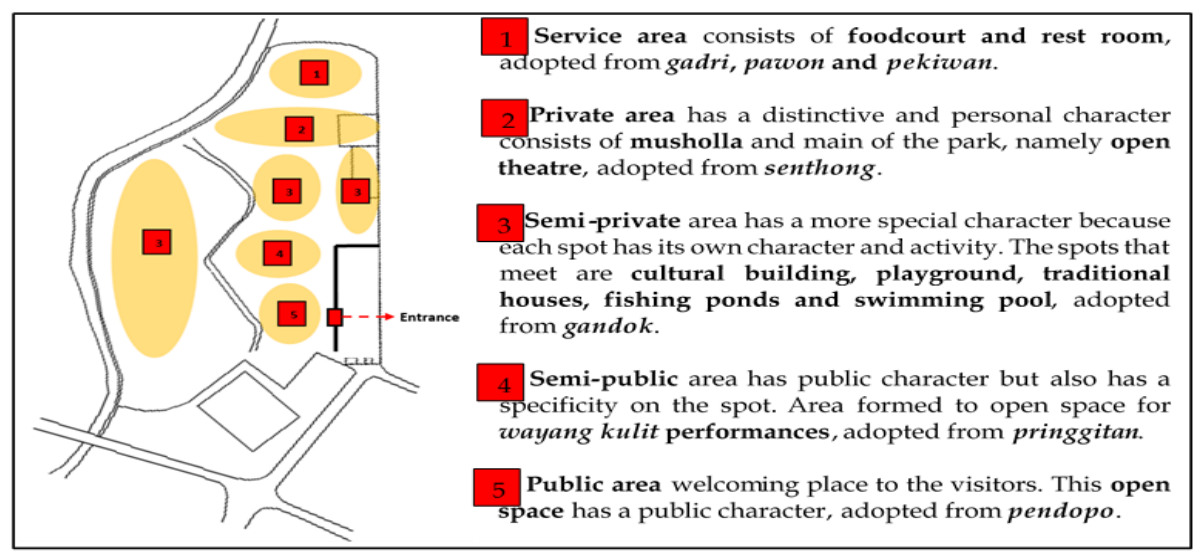

Figure 7. Schematic Design of Javanese House Concept Adaptation Implementation. source:

(Author, 2020) 


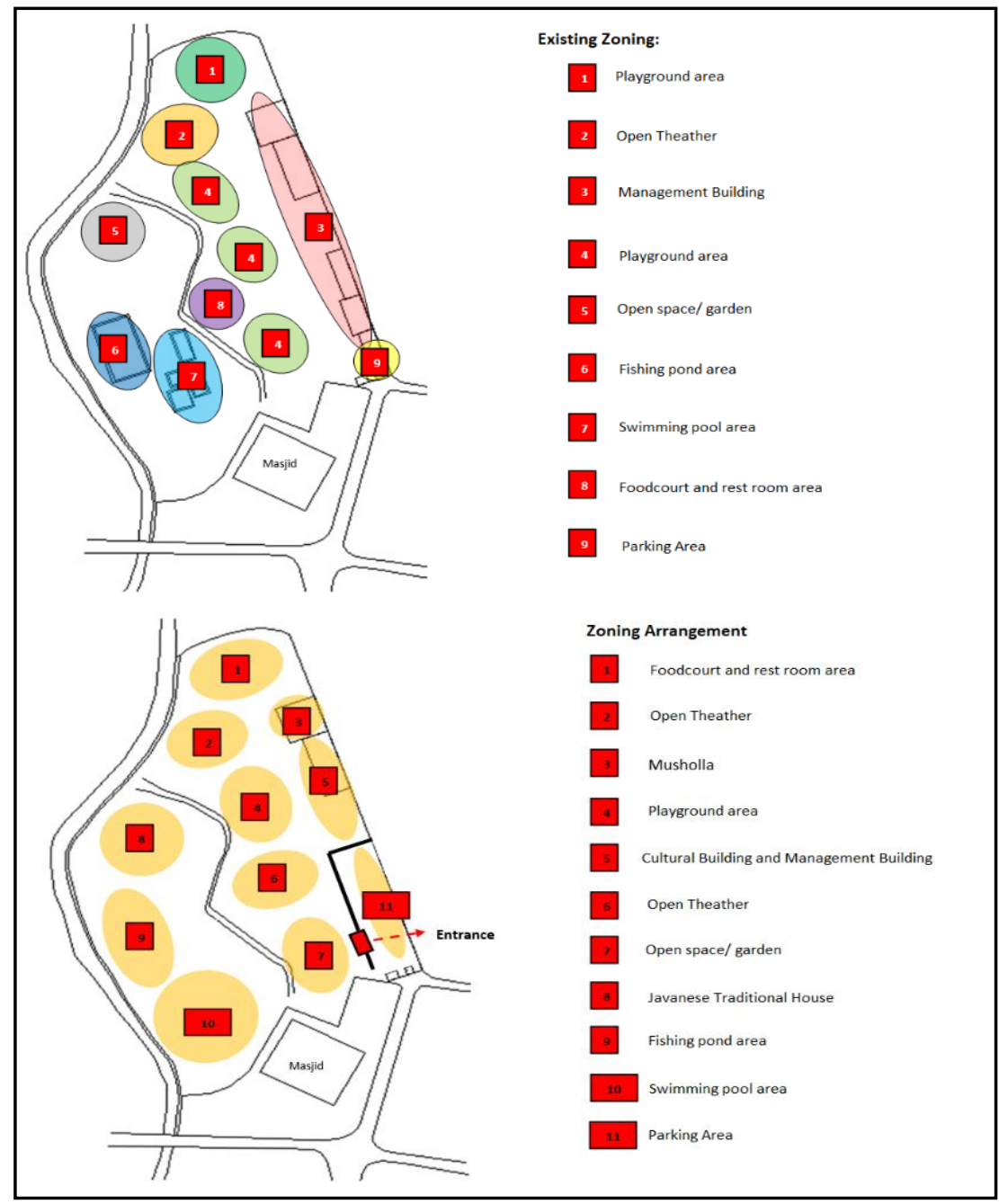

Figure 8. Landscape Zoning Design Direction. source: (Author, 2020)

\section{CONCLUSION}

The preferences and perception of modern communities at cultural tourism park is very low. As the study shown that only $17.96 \%$ people knowing and considering cultural tourism park importances and existences, others $82.04 \%$ people admire at modern park very well. The The existence of the Senaputra Cultural Tourism Park is one effort of maintaining the Indonesian's culture in modern times. Revitalization efforts through landscape design directives is expected to be a guide material for revitalization activities and can provide added cultural value so that the Senaputra Cultural Tourism Park, which is thick with Javanese traditional culture, is again in demand by modern society and the Indonesian culture is maintained from time to time.

\section{REFERENCE}

Departemen Pekerjaan Umum Direktorat Jederal Bina Marga. (2010). (Road Landscape Engineering Planning Procedures) Tata Cara Perencanaan Teknik Lansekap Jalan. Jakarta: Bina Marga. 
Spatial Adaptation of Traditional Javanese Houses in Landscepe Design of Senaputra Cultural Tourism Park

Stivani Ayuning Suwarlan

Frick, Heinz. (1997). (Structural Patterns and Building Techniques in Indonesia) Pola Struktural dan Teknik Bangunan di Indonesia. Kanisius dan Soegijapranata University Press: Yogyakarta.

Gamal, S. (2004). (Tourism basics) Dasar-Dasar Pariwisata. Andi: Yogyakarta.

Hidayati, Sri. (2000). (Urban Revitalization in Several Countries) Peremajaan Kota di Beberapa Negara.

Junianto, Rosalia N.S. Lestari \& Achmad T. Subadyo. (2019). Revitalization Concept Patirtan Sites as a Sustainable Spiritual Tourism in Malang, East Java. Jurnal Local Wisdom, Vol: 11 No. 2, 132-137.

Kartono, J. Lukito. (2005). (The Concept of Traditional Javanese Space in Cultural Context) Konsep Ruang Tradisional Jawa dalam Konteks Budaya. Makalah disajikan dalam seminar PPKAI, Universitas Kristen Petra, Surabaya, 2 Mei 2005.

Kirom, R. Novita. (2016). (Determinants of Cultural Tourism Attractions and Their Influence on Tourist Satisfaction) Faktor-Faktor Penentu Daya Tarik Wisata Budaya Dan Pengaruhnya Terhadap Kepuasan Wisatawan. Pendidikan, I (3): 536-546.

Lake, R.C., Yohanes D. Purbadi \& Herman F. Harmans. (2020). Identification and Orientation on Spatial Arrangement of Wajo Traditional Village, Keo Tengah, Nagekeo Regency. Jurnal Local Wisdom, Vol: 12 No. 1, 19-30. https:/ / doi.org/10.26905/lw.v.12i1.3581

Mattulada, H.A. (2000). (Revitalization and Reactualization of Local Culture to Strengthen National Unity). Revitalisasi dan Reaktualisasi Budaya Lokal untuk Memperkokoh Kesatuan Nasional. Makalah disajikan dalam seminar di Bandung 5,6,7 Agustus 2000.

Ministry For The Environment. (2009). Urban Design Toolkit Third Edition. Ministry for The Environment: Wellington.

Muchhibi, I. K. (2015). (Mangrove Park Planning in Morosari Demak Beach Area as a Means of Education and Recreation (Emphasis on Ecological Architecture Design) Perencanaan Mangrove Park di Kawasan Pantai Morosari Demak sebagai Sarana Edukasi dan Rekreasi (Penekanan Desain Arsitektur Ekologis). Canopy, II (1): 12-21.

Muhadjir, N. (1996). (Qualitative research method) Metode Penelitian Kualitatif. Rake Sarasin: Yogyakarta.

Peraturan Walikota Surabaya Nomor 85 tentang Tata Cara Penyelenggaraan Reklame. (2006). Surabaya: Pemko Surabaya.

Prasodjo, Tunggul. (2017). (Cultural Tourism Development in Public Service Perspective) Pengembangan Pariwisata Budaya dalam Perspektif Pelayanan Publik. Office, III (1): 7-12.

Sari, Wahyuni Eka. (2020). The Morphology of Hierarchy Limasan House Space in Kertosari Ponorogo. Jurnal Local Wisdom, Vol: 12 No. 1, 1-9. https:/ / doi.org/10.26905/lw.v.12i1.3615

Sidarta \& Eko Budiharjo. (1989). (Environmental Conservation and Historical Ancient Buildings in Surakarta) Konsevasi lingkungan dan Bangunan Kuno Bersejarah di Surakarta. Gajah Mada University Press: Yogyakarta. 
Spatial Adaptation of Traditional Javanese Houses in Landscepe Design of Senaputra Cultural Tourism Park

Stivani Ayuning Suwarlan

Siregar, Sofyan. (2016). (Descriptive Statistics for Research Equipped with Manual Calculations and SPSS Application Version 17) Statistika Deskriptif untuk Penelitian Dilengkapi Perhitungan Manual dan Aplikasi SPSS Versi 17. PT Raja Grafindo Persada: Jakarta.

Sugiyono. (2018). (Quantitative research method) Metode Penelitian Kuantitatif. Alfabeta: Bandung.

Taylor, E. B. (1871). Primitive Culture. John Murray: London. 